\title{
Sugarcane root distribution and growth as affected by genotype and crop cycle
}

\author{
Liping Zhao 1,2 (D), Kun Yang ${ }^{1,2}$ (D), Peifang Zhao ${ }^{1,2}$ (D), Wei Qin 1,2 (D), Yong Zhao ${ }^{1,2}$ (D), Jianrong Zhu'1,2 (D), \\ Fenggang Zan ${ }^{1,2}$ (D), Jun Zhao ${ }^{1,2}$ (D), Xin Lu ${ }^{1,2}$ (D), Caiwen Wü ${ }^{1,2}$ (D), David M. Burner ${ }^{1}$ (D), \\ Xuekuan Chen ${ }^{1,2}$ (D), Jiayong Liu ${ }^{1,2, \star}$ (D) \\ 1. Yunnan Sugarcane Research Institute, Yunnan Academy of Agricultural Sciences, Kaiyuan (Yunnan), China. \\ 2. Yunnan Key Laboratory of Sugarcane Genetic Improvement, Kaiyuan (Yunnan), China.
}

\begin{abstract}
Sugarcane (Saccharum L. spp. hybrids) is a globally important crop. While roots contribute to its net primary production, knowledge of sugarcane root growth is incomplete and limited in scope. The objective of this study was to determine cumulative root density $\left(L_{A}\right)$, root distribution, effective rooting depth (ERD), and root growth rate for four sugarcane genotypes across three crop cycles (plant cane [PC], first ratoon [FR], and second ratoon [SR]). The experiment was conducted in a rain shelter on four sugarcane genotypes (ROC22, YZO4-241, YZ05-194, and YZ05-51) using minirhizotron tubes to a soil profile depth of $1.08 \mathrm{~m}$. Most roots in were found at 0-0.36 m-depth, and about $85.0 \%$ were within a 0-0.72 m depth in PC. In FR and SR, however, $>81.8 \%$ of roots were found at $0-0.54$ m-depth regardless of genotype. The $L_{A}$ of ROC22 was often significantly higher than that of the other genotypes at depths $<0.54 \mathrm{~m}$ regardless of crop cycle. The genotype ROC22 had greater root length and faster root growth rate than YZO5-194 at 0.18-0.36 m in PC and FR, while SR YZ05-194 had slower root growth than the other genotypes at $0-0.18 \mathrm{~m}$. Ratooning ability of sugarcane genotypes may be related to these root growth attributes.
\end{abstract} KEY WORDS: Saccharum, minirhizotron, root density, effective root depth, root growth rate.
Received: Oct. 17, 2019

Accepted:

Mar. 3, 2020

Section Editor: Gabriel Constantino Blain

${ }^{\star}$ Corresponding author: Ilijyy1976@163.com

\section{INTRODUCTION}

Sugarcane (Saccharum L. spp. hybrids) is a globally important economic crop cultivated across an array of environments in the tropics and subtropics (FAO 2014). Knowledge of root dynamics in the rhizosphere is fundamental to understanding nutrient and water uptake (Smith et al. 2005), and is intimately linked with sugarcane growth and yield forecasting (Wu et al. 2014).

In contrast to canopy traits, relatively little is known about sugarcane root systems and this could affect the ability to optimize yield potential. There is little empirical data on management practices and soil physical, chemical, and biological factors that might affect root distribution (Vasconcelos et al. 2003), or if genotype and crop cycle (plant cane vs. ratoon crop) affects root growth and distribution dynamics (Ohashi et al. 2015). Much of the existing literature on root growth and distribution is dated (Ball-Coelho et al. 1992) or location-specific (Laclau and Laclau, 2009; Otto et al. 2009; Vasconcelos et al. 2003).

The adoption of new technologies (agronomy, breeding, and mechanization) requires updated information on root distribution, but there are methodological difficulties associated with nondestructive root sampling and imaging (Muñoz-Romero et al. 2010). A minirhizotron miniature video camera technique was developed to characterize root dynamics (Box Junior 1993), but it was seldom used in sugarcane. Soil core sampling combined with root intersection analysis was used to analyze root distribution at three sugarcane growth stages (Azevedo et al. 2011) and during the crop cycle (Laclau and Laclau 2009). Azevedo et al. (2011) and Laclau and Laclau (2009) found a strong genetic control of root growth in deep soil layers, and that it was necessary to account for the development of sugarcane roots in deep soil layers to improve the understanding of net primary production. 
Minirhizotron studies have been conducted on sugarcane under rainfed conditions (Ball-Coelho et al. 1992) and in a subsurface drip irrigation practice (Ohashi et al. 2015), but there were no recent minirhizotron studies on sugarcane in rain shelters across crop cycles. The objective of this study was to determine root length density $\left(\mathrm{L}_{\mathrm{A}}\right)$, total root length (L), root growth rate (RGR), root distribution and effective rooting depth (ERD), yield traits, yield and root correlations for four sugarcane genotypes across three crop cycles: plant cane (PC), first ratoon (FR), and second ratoon (SR) crops. The authors hypothesized that genotypes would show a consistent relationship between aboveground performance and rooting attributes.

\section{MATERIALS AND METHODS}

\section{Study sites, plant materials, and experimental design}

The experiment was conducted at the Yunnan Sugarcane Research Institute (YSRI) in Kaiyuan City $\left(103^{\circ} 15^{\prime} \mathrm{E}, 23^{\circ} 42^{\prime} \mathrm{N}\right)$, Yunnan Province, in southwest China under a fixed-location, open top rain shelter (Yahdjian and Sala, 2002). The rain shelter was $4.4 \mathrm{~m}$-tall $\times 400 \mathrm{~m}^{2}$ (10 m-wide $\times$ long $40 \mathrm{~m}$-long).

The soil was a clay loam (Zhao et al. 2019). Soil at the prospective site was sampled by auger to a depth of $0.4 \mathrm{~m}$ and analyzed at YSRI using standard methods (Lu 2000). Mean values for three replicates of soil were $19.2 \mathrm{~g}^{\mathrm{kg}} \mathrm{organic} \mathrm{matter,}^{-1}$ $85.3 \mathrm{mg} \cdot \mathrm{kg}^{-1}$ total N, $57.5 \mathrm{mg} \cdot \mathrm{kg}^{-1}$ available $\mathrm{P}, 87 \mathrm{mg} \cdot \mathrm{kg}^{-1}$ available $\mathrm{K}$, and $\mathrm{pH} 7.5$.

Minirhizotron tubes $(7 \mathrm{~cm}$ external diam $\times 1.80 \mathrm{~m}$-length, CID Bio-Science Inc., Camas, Washington, USA) were installed in each prospective plot. The above-ground portion of the tube (about $0.25 \mathrm{~m}$-long) was covered with dark plastic to prevent light and water entry. Eight acrylic minirhizotron tubes were installed in each single-row plot area in August 2013 (16 tubes per genotypes), and at a $45^{\circ}$ angle to the soil surface (64 total tubes in the study). The bottom of the tube terminated at an imaginary center line below the sugarcane row. The soil was allowed to stabilize around the tubes for 12 months post-installation, prior to image acquisition (Fig. 1).

Four sugarcane genotypes (ROC22, YZ04-241, YZ05-194, and YZ05-51) were tested in PC, FR, and SR crops. The genotypes ROC22 and YZ05-51 were commercial cultivars (Zhao et al. 2016), while YZ05-194 and YZ04-241 were advanced stage selections from the commercial breeding program and not commercially released. Genotype ROC22 was specifically included because it is widely-grown in China, and is characterized by high bud germination, abundant tillering, rapid growth, tall plant height, good self-trashing, lodging resistance, minimal flowering in the field, good ratooning ability, and drought resistance (Zhao et al. 2016). Genotype YZ05-51 was released by the China Committee of Sugarcane Variety because of it is smut resistance, high cane and sugar yields, drought resistance, moderate resistance to mosaic virus (Sorghum mosaic and Sugarcane mosaic), and a semiperennial ratooning ability (Zhao et al. 2015). Genotype YZ05-194 was tall-statured, with little tillering or ratooning ability, and had good self-trashing and high sugar yields. Genotype YZ04-241 had medium plant height, good self-trashing, semiperennial ratooning ability, low sugar yield, and readily flowered in the field.
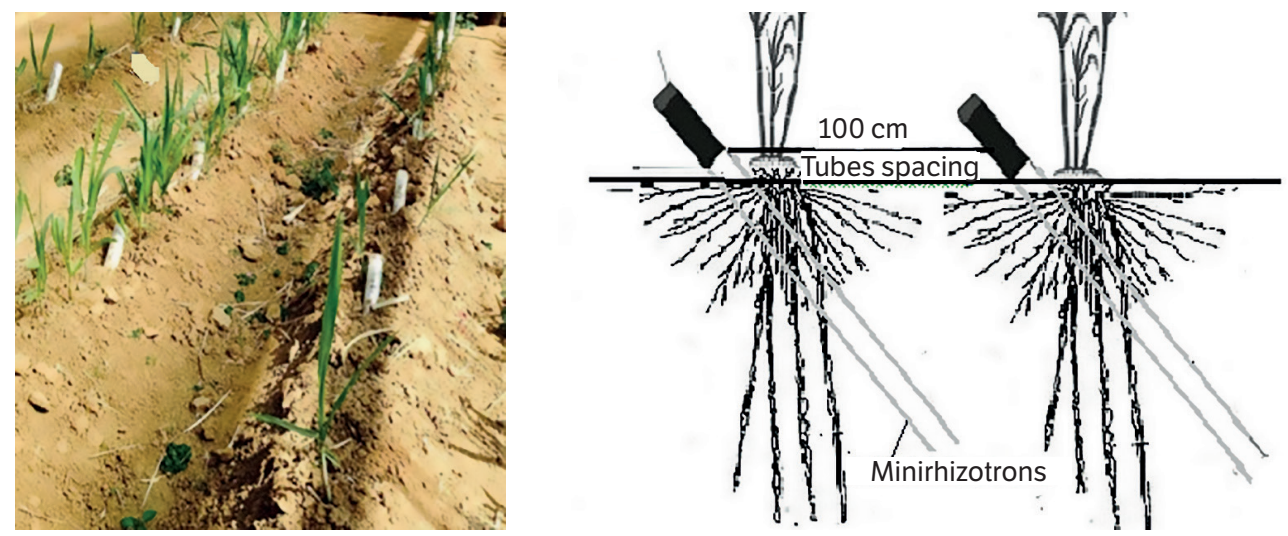

Figure 1. Experimental plot with installed minirhizotrons at Kaiyuan, China (left), and sketch of minirhizotron tube positions (right). 
Experimental plots were arranged in a block design $(n=2)$ with two rows $(8 \mathrm{~m}$-long $\times 1.5 \mathrm{~m}$ between rows $)$ of each cultivar ( 16 tubes per cultivar). Genotypes were planted on 30 July 2014 after treating the bud setts with hot water $\left(50 \pm 0.2^{\circ} \mathrm{C}\right)$ for $2 \mathrm{~h}$ to reduce infection by ratoon stunting disease (Leifsonia $x y l i$ subsp. $x y l i$ ). This pathogen reduces sugarcane yield particularly during water stress (Steindl, 1961). Planting and cultivation followed local commercial cropping practices (Liu et al. 2016; Zhao et al. 2016). Care was taken to assure that sugarcane planting did not disturb the minirhizotron tubes.

Plants were irrigated regularly to minimize water stress. At each irrigation approximately $90 \mathrm{~mm}$ of water was applied by spray irrigation. Crop-specific irrigations were initially applied to ensure good germination after planting the PC crop (5 August 2014), and harvesting of the FR (28 February 2015) and SR (1 December 2015) crops. Subsequent irrigations were applied on 3 October and 8 December 2014 (PC); 5 April, 20 June, 24 August, and 22 October 2015 (FR); and 11 April, 13 June, 10 August, and 11 October 2015 (SR). Annual broadcast applications of commercial fertilizers supplied $345 \mathrm{~kg} \cdot \mathrm{ha}^{-1}$ $\mathrm{N}, 144 \mathrm{~kg} \cdot \mathrm{ha}^{-1} \mathrm{P}$, and $90 \mathrm{~kg} \cdot \mathrm{ha}^{-1}$ to each crop.

\section{Weather data}

Air temperature data and rainfall were continuously recorded on site during the study period using a model HMP155A sensor (Campbell Scientific, Inc., Logan, Utah, USA). The temperature sensor was situated about $3 \mathrm{~m}$ above the soil surface. No data were collected in 2014.

\section{Plant growth data}

Plots were sequentially hand-harvested in PC after 206 d growth (28 February 2015), FR after 275 d growth (1 December 2015), and SR after $369 \mathrm{~d}$ growth (5 December 2016). Stalk height, stalk diameter, number of stalks, and yield (t cane $\cdot \mathrm{ha}^{-1}$ or TCH) were measured at each ratoon harvest (Liu et al. 2016).

\section{Analysis of root system}

Image acquisition began on 5 September 2014. Tubes were imaged 27 times during the growing season for each of the three crops, or about once every $2 \mathrm{wk}$ during PC, and about once each month during FR and SR crops. Six $360^{\circ}$ images tube $^{-1}$, one image ( $21.96 \mathrm{~cm}$-diam $\times 19.56 \mathrm{~cm}$-long) per depth increment was acquired at each sampling date. Depth increments were $0-0.18,0.18-0.36,0.36-0.54,0.54-0.72,0.72-0.90$, and 0.90-1.08 m. Imaging used the Root Scanner CI-600 (CID BioScience Inc., Camas, Washington, USA). Images were analyzed using WinRHIZO Tron 2007b software (Regent Instruments Inc., Quebec, Canada). For each tube, root length (L) was initially obtained from the software. Cumulative root density $\left(\mathrm{L}_{\mathrm{A}}, \mathrm{mm} \cdot \mathrm{cm}^{-2}\right)$ was estimated as $\mathrm{L}$ normalized by the $422.30 \mathrm{~cm}^{2}$ sampling area of each window (Smit et al. 2000), totaling $0.25338 \mathrm{~m}^{2}$ per tube. Root growth rate (RGR) was the increase in $\mathrm{L}_{\mathrm{A}}$ between two consecutive samplings and the time (d) between samplings. Effective rooting depth (ERD) was calculated as the depth in which $80 \%$ of the fine roots were found (Cunha et al. 2010) and were also presented as percentages to facilitate comparisons with other studies.

\section{Statistical analysis}

Stalk height, stalk diameter, and number of stalks were averaged for each plot in ratoon crops. Root traits $\mathrm{L}_{\mathrm{A}}$ and RGR were averaged in PC (September to February), and FR and SR (April to November). Total root length was the sum of measurements across sampling dates for each crop. Analysis of variance for each variable cane yield, height, stalks, stalk diameter, $\mathrm{L}_{\mathrm{A}}$, L, RGR, and ERD used GLM method of SPSS 21. Significant differences between genotype means were compared using Tukey's test $(P<0.05)$. Pearson correlations between plant traits and root traits in the three crops were calculated using SPSS 21. Regression analyses and generation of figures used OriginPro 2018. 


\section{RESULTS AND DISCUSSION}

As was typical for most sugarcane production regions in China, relatively little rainfall occurred in winter and spring, while the wet season typically commenced in early summer extended to early autumn. Daily mean air temperatures ranged from 7 to $31^{\circ} \mathrm{C}$ in 2015 , and 2 to $30^{\circ} \mathrm{C}$ in 2016. During the period from April to November, there were few days with maximum air temperatures $>35^{\circ} \mathrm{C}$ (data not shown), and minimum air temperatures $<10^{\circ} \mathrm{C}$ tended to be infrequent after November. In FR (2015), extreme daily maximum and minimum air temperatures were 37 and $2{ }^{\circ} \mathrm{C}$, respectively. Corresponding daily extremes in SR (2016) were 37 and $2^{\circ} \mathrm{C}$, respectively. Monthly air temperature mean, mean maximum, and mean minimum temperatures for FR were 22,29 , and $17^{\circ} \mathrm{C}$, and those for SR were 21,27 , and $16^{\circ} \mathrm{C}$, respectively (Fig. 2 ).

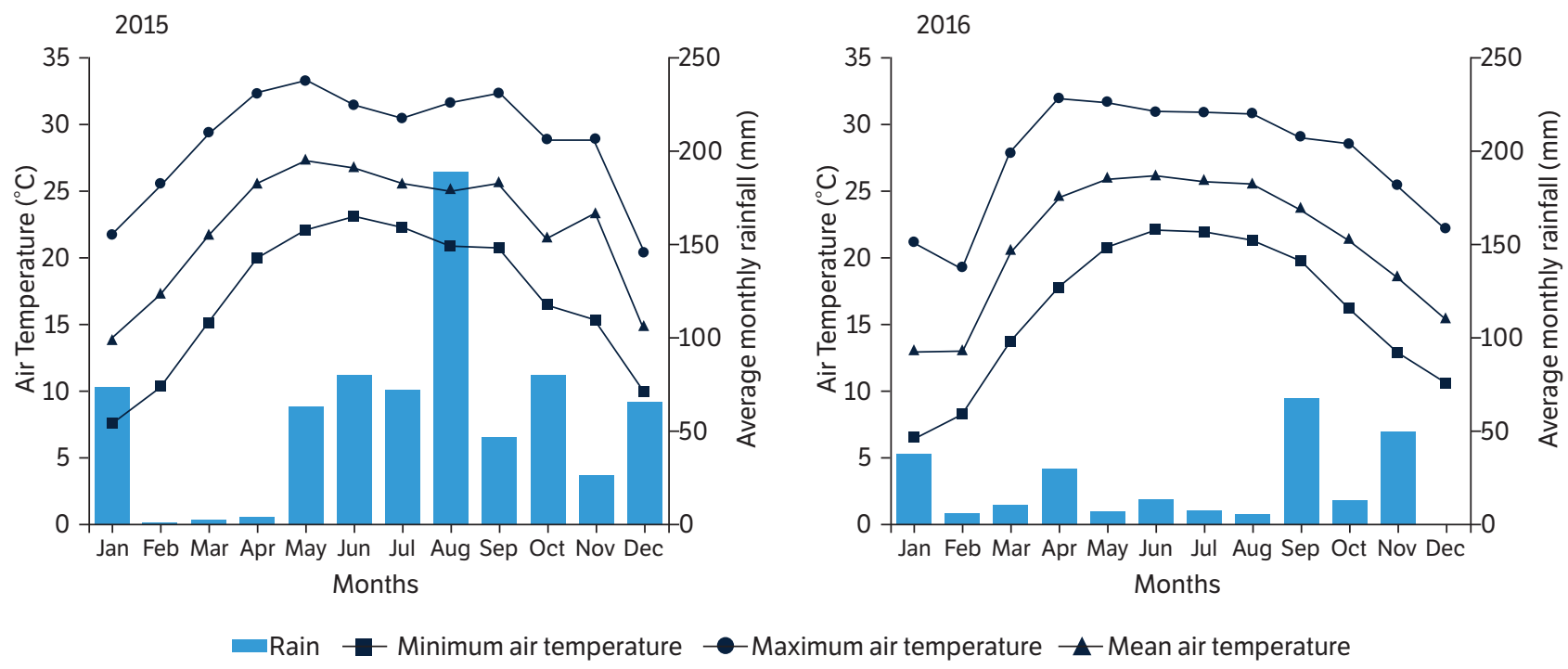

Figure 2. Average monthly rainfall, monthly maximum, minimum, and mean air temperatures at Kaiyuan, China in 2015 (plant cane to first ratoon) and 2016 (first ratoon to second ratoon).

\section{Root length density $\left(L_{A}\right)$}

The $\mathrm{L}_{\mathrm{A}}$ of ROC22 was often significantly greater than that of YZ05-194 at depths smaller than $0.54 \mathrm{~m}$ regardless of crop cycle (Fig. 3). Moreover, genotypes did not differ in $\mathrm{L}_{\mathrm{A}}$ at soil depths more than $0.54 \mathrm{~m}$ in any crop cycle. In FR, ROC22 had higher absolute $\mathrm{L}_{\mathrm{A}}\left(3.10 \mathrm{~mm} \cdot \mathrm{cm}^{-2}\right)$ than the other genotypes $\left(1.67-2.65 \mathrm{~mm} \cdot \mathrm{cm}^{-2}\right)$ at $0-0.36 \mathrm{~m}$. But in $\mathrm{SR}, \mathrm{L}_{\mathrm{A}}$ tended to be lower than in PC and FR regardless of depth, and was essentially zero at depths more than $0.18 \mathrm{~m}$.

Considering the use of minirhizotron method to evaluate sugarcane root system under field conditions, Ball-Coelho et al. (1992) estimated a mean root length intensity value of $0.27 \mathrm{~mm} \cdot \mathrm{cm}^{-2}$ up to $1.5 \mathrm{~m}$ depth. These values are lower than the observed in this study, but it is important to highlight that Ball-Coelho et al. (1992) considered the mean value up to $1.5 \mathrm{~m}$ depth, Ohashi et al .(2015) estimated the highest $\mathrm{L}_{\mathrm{A}}$ values of 3.6-12.9 $\mathrm{mm} \cdot \mathrm{cm}^{-2}$. These values are higher than the observed in this study, Ohashi et al. (2015) considered the highest $\mathrm{L}_{\mathrm{A}}$ value under subsurface drip fertigation and up to $0.8 \mathrm{~m}$ depth.

\section{Total root length (L)}

There were significant differences in $\mathrm{L}$ at soil depths $0-0.18 \mathrm{~m}$ (Fig. 4c), 0.18-0.36 m (Fig. 4a-c), and 0.36-0.54 m (Fig. 4a). At these depths, L of ROC22 was significantly greater than that of YZ05-194. In PC, L of ROC22 was significantly greater than YZ05-51, YZ05-194 and YZ04-241 at 0.18-0.36 m (Fig. 4a). In FR, L of ROC22 and YZ05-51 was significantly 

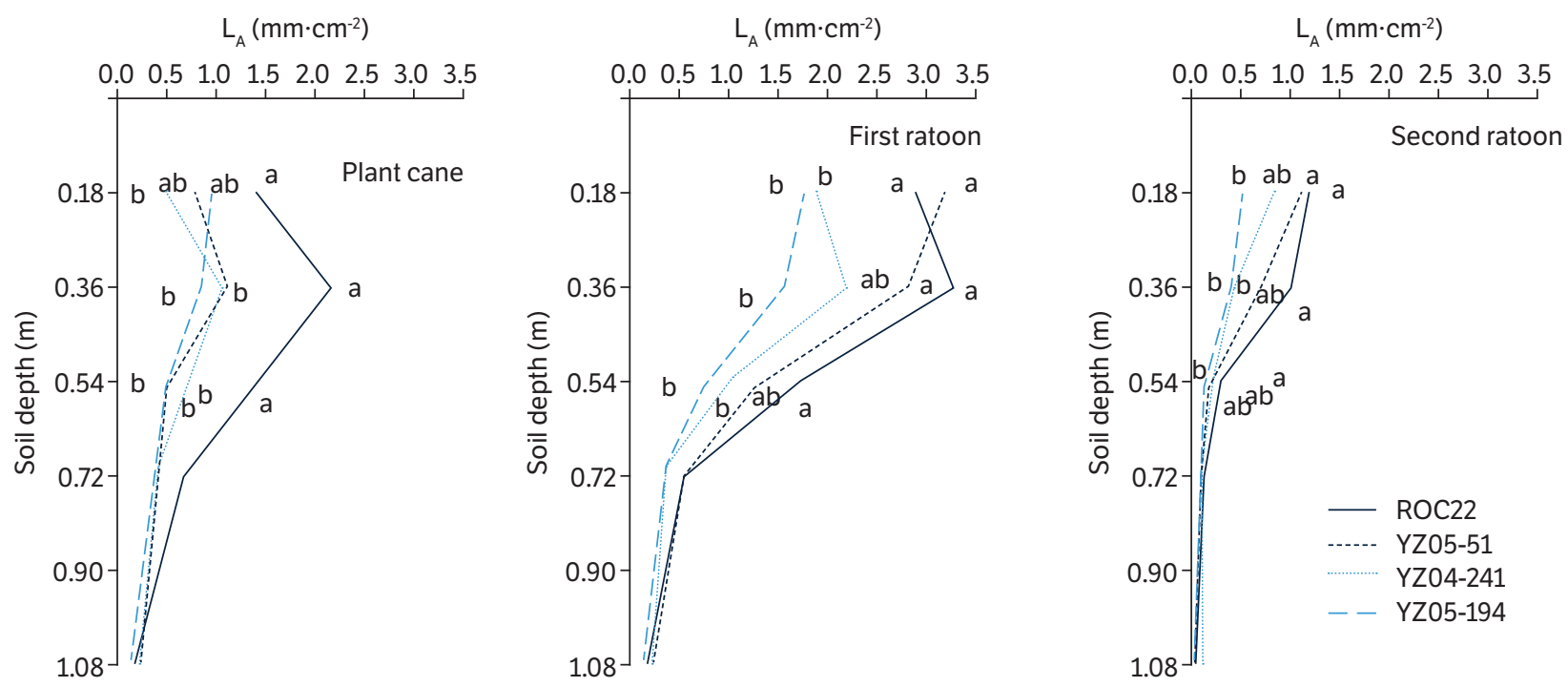

Figure 3. Cumulative root density $\left(L_{A}\right)$ of sugarcane genotypes ROC22, $Y Z 04-241$, $Y Z 05-194$, and $Y Z 05-51$ as affected by crop cycle and soil depth. Different letters at a given depth indicate that means differed $(p \leq 0.05)$. Space constraints limited the number of letters that could be shown. For each crop there were no significant differences at depths $\geq 0.72 \mathrm{~m}$.

(a) Total root length $\mathrm{PC}(\mathrm{mm})$

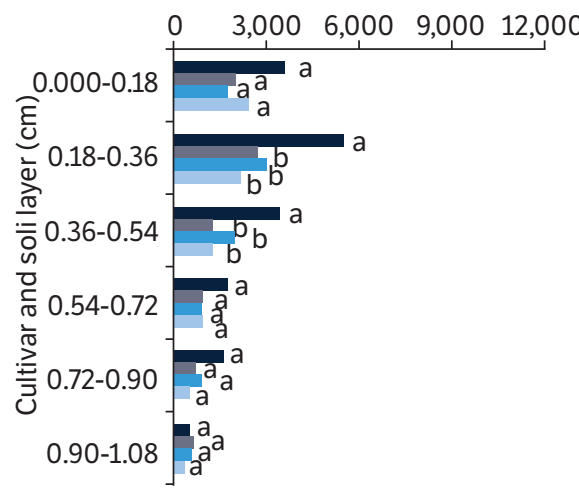

(b) Total root length FR ( $\mathrm{mm})$

(c) Total root length SR (mm)

Figure 4. Total root length distribution of sugarcane genotypes ROC22, YZ04-241, YZ05-194, and YZ05-51 as affected by crop cycle and soil depth. (a) Plant cane (PC), (b) first ratoon (FR), (c) second ratoon (SR). For each crop and depth, genotypes with the same letter do not differ at $p \leq 0.05$ according to SPSS.

greater than YZ05-194 at 0.18-0.36 m (Fig. 4b). In SR, L of YZ05-194 was significantly smaller than that of the other genotypes at 0-0.18 m, and L of ROC22 was significantly greater than that of YZ05-194 and YZ04-241 at 0.18-0.36 m (Fig. 4c). Except for these genotypes and depths mentioned, genotypes did not differ significantly at other soil depths or crop cycles; although ROC22 often tended to have greater absolute mean L than the other genotypes. Roots were mainly distributed at a 0-0.54 m-depth in PC, and at a 0-0.36 m-depth in FR and SR. Root length was greatest in FR (Fig. 4b). Regression analysis across genotypes (Fig. 5) showed that the L to soil depth trends of PC and FR had similar intercepts and slopes, while for SR, $\mathrm{L}$ of the four genotypes decreased at a rapid rate from a nearly 3 -fold greater intercept at $0.18 \mathrm{~m}$ to nearly 0 at about $1 \mathrm{~m}$ depth.

Total $\mathrm{L}$ ranged from 3.68 to $28.17 \mathrm{~m}$ across depths and genotypes (Fig. 4a-c), demonstrating the relatively large values that were measured in the small area of observation $\left(0.16892 \mathrm{~m}^{2}\right)$ minirhizotrons.

Several researchers have studied sugarcane root systems using various methods, making it difficult to compare values (Azevedo et al. 2011; Laclau and Laclau 2009; Otto et al. 2009; Ohashi et al. 2015; Vasconcelos et al. 2003). However, they all reported large variability in L. Using a subsurface drip system, Ohashi et al. (2015) measured L of 10.8, 5.9 and $2.5 \mathrm{~m}$ at 

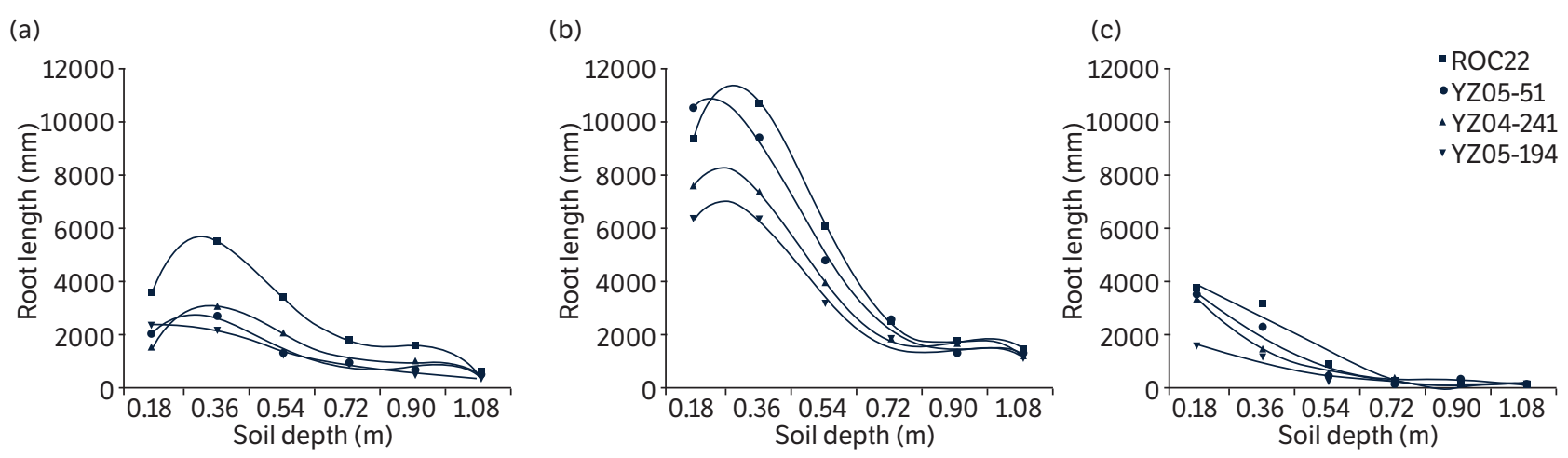

Figure 5. Regression analysis of root length with soil depth for ROC22, YZ04-241, YZ05-194, and YZ05-51. a) plant cane (PC), b) first ratoon (FR), c) second ratoon (SR).

depths up to $0.8 \mathrm{~m}$. These $\mathrm{L}$ values differed from what was measured in this study, but that was attributed to methodological and environmental differences between studies. This experiment study was conducted under a fixed-location, open top rain shelter. Root growth depends on plant genotype, soil biology and physicochemical status, crop management (Vasconcelos et al. 2003), and soil water availability (Laclau and Laclau 2009; Smith et al. 2005). Root dynamic studies should be conducted using similar methods if they are to be compared.

\section{Root growth rate (RGR)}

The greatest RGR occurred between 136 and 155 DAP in PC, 197 and 225 DAR1 in FR and 138 and 168 DAR2 in SR (Fig. 6a). The maximum RGR was $64.38 \mathrm{~mm} \cdot$ day $^{-1}$ (PC) and $62.50 \mathrm{~mm} \cdot$ day $^{-1}$ (FR) in ROC22 at the $0.18-0.36 \mathrm{~m}$ soil layer, while YZ 05-51 had the highest RGR of $61.49 \mathrm{~mm} \cdot$ day $^{-1}$ in FR at the $0.18-0.36 \mathrm{~m}$ soil layer. This was smaller than RGR reported by Smith et al. (2005) of $80 \mathrm{~mm} \cdot$ day $^{-1}$, and Ohashi et al. (2015) of $82 \mathrm{~mm} \cdot$ day $^{-1}$ due to environmental differences. The highest RGR occurred when air temperature varied between 20.7 and $32.5^{\circ} \mathrm{C}$ (FR), and 22.1 and $30.9^{\circ} \mathrm{C}$ (SR) (Fig. 2). Ohashi et al. (2015) estimated the highest growth rates occurred when air temperature varied between 25.0 and $27.9^{\circ} \mathrm{C}$.

In PC, ROC22 had significantly faster RGR than YZ04-241 and YZ05-194 at 0.18-0.36 m (Fig. 6b). In FR, ROC22 and YZ05-51 had significantly faster RGR than YZ05-194 at 0.18-0.36 m (Fig. 6c), while in SR, YZ05-194 had slower RGR than the other genotypes at 0-0.18 m (Fig. 6d). Except for these depths, genotypes did not differ significantly at other soil depths or crop cycles. In general, ROC22 often had greater absolute mean RGR than the other genotypes. It was observed that RGR decreased with increase in soil depth. The mean RGR was $46.13 \mathrm{~mm} \cdot \mathrm{d}^{-1}$ in ROC22 at the $0.18-0.36 \mathrm{~m}$ soil layer in FR (Fig. 6c), which is similar to a study by Smith et al. (2005), who reported mean RGR of $40 \mathrm{~mm} \cdot \mathrm{d}^{-1}$. Similarly, Smit and Groenwold (2005) reported that grasses had RGR of growth rate decreased considered about $20 \mathrm{~mm} \cdot \mathrm{day}^{-1}$. But in the SR, RGR of the four genotypes decreased, possibly due to a decrease in root function.

The minirhizotron method allowed to observe changes in L and RGR, and confirmed that sugarcane root distribution was greater in the upper soil profile in each crop cycle (Gascho and Shih, 1983). Understanding RGR across crop cycles might be related to overall plant growth phenology, which could facilitate research in irrigation, nutrition management, and plant breeding.

There was a tendency for RGR of individual genotypes to decrease in SR. The higher growth rates of ROC22 and YZ0551 could be related to their fast-initial vegetative growth and high yield.

\section{Root distribution and effective rooting depth (ERD)}

Most roots in this study were found in a $0-0.36 \mathrm{~m}$-deep soil region (59.2\% in PC, data not shown), and about $88.2 \%$ were at $0-0.72 \mathrm{~m}$-depth. During ratooning, most roots were found in a $0-0.36 \mathrm{~m}$-deep soil region $(72.0 \%$ in FR and $80.3 \%$ in SR), and about $88.7 \%$ were at $0-0.54 \mathrm{~m}$-depth. Thus, ERD was $0.72 \mathrm{~m}$ in PC and $0.54 \mathrm{~m}$ in FR and SR (Fig. 7). 
(a)

Root growth rate
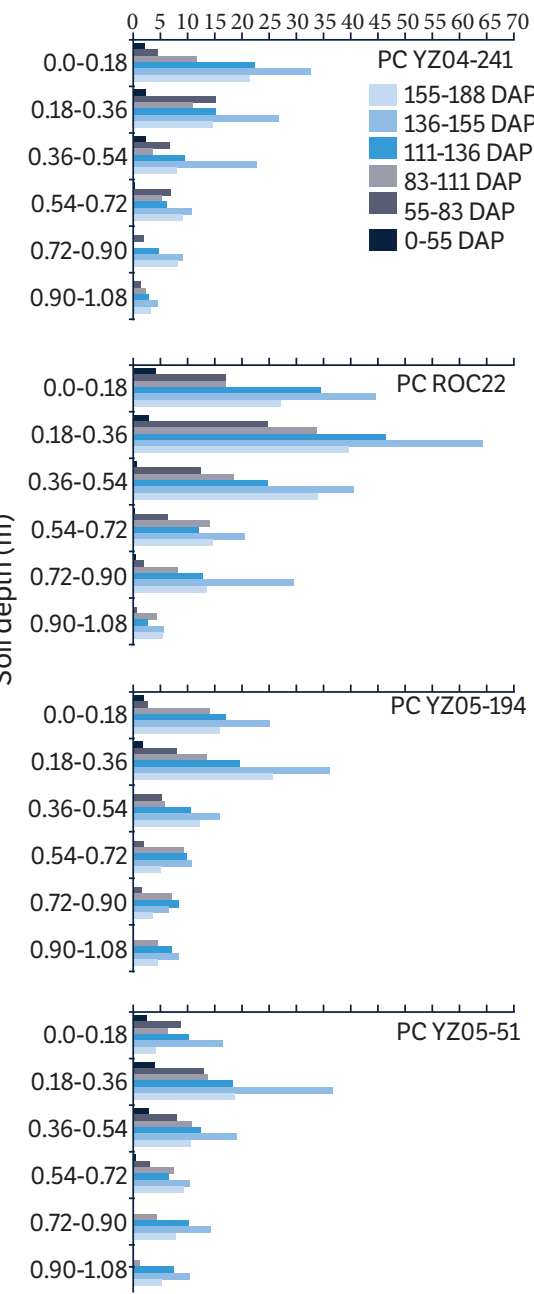

(b)

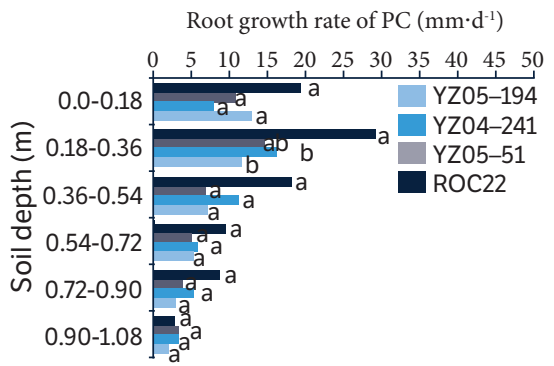

Root growth rate
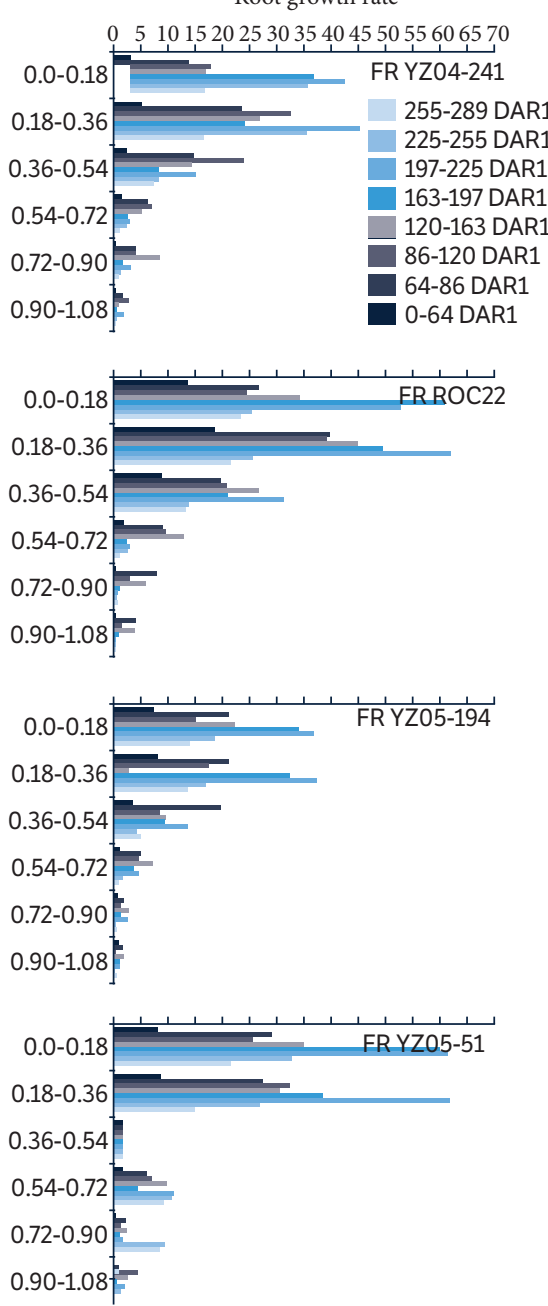

(c)

Root growth rate of FR $\left(\mathrm{mm} \cdot \mathrm{d}^{-1}\right)$

$\begin{array}{lllllllllll}0 & 5 & 10 & 15 & 20 & 25 & 30 & 35 & 40 & 45 & 50\end{array}$

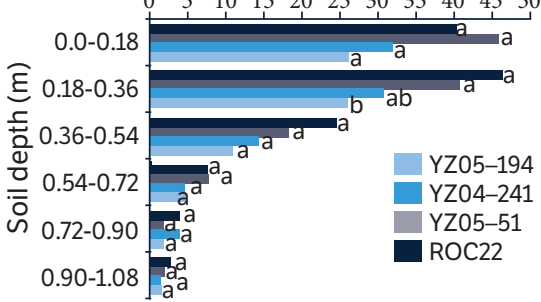

Root growth rate
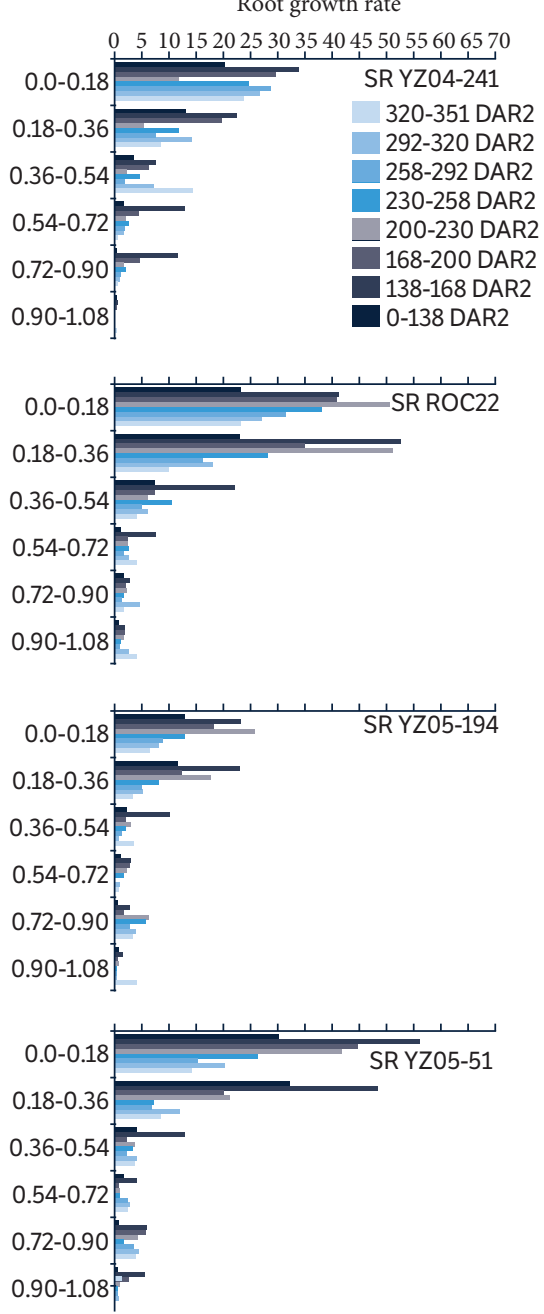

(d)

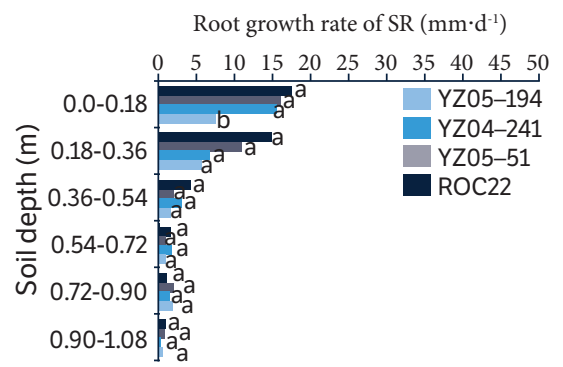

Figure 6. Root growth rate in each soil layer up to 1.08 m depth for sugarcane genotypes ROC22, YZ04-241, YZ05-194, and YZ05-51 in different assessments periods (a), and overall root growth rate in 188 (b), 289 (c) and 351 days (d). b) Plant cane (PC), c) first ratoon (FR), d) second ratoon (SR). For each crop and depth, genotypes with the same letter do not differ at $p \leq 0.05$ according to SPSS.

The ERD results in this study were roughly comparable to other studies. Otto et al. (2009) found $65 \%$ of root mass in the top $0.2 \mathrm{~m}$ soil depth for genotype SP81-3250. Similar results were reported by Vasconcelos et al. (2003), with 52\% of root mass in the superficial soil layer. Otto et al. (2009) found more than $80 \%$ of root mass was within the $0-0.4 \mathrm{~m}$ depth. While they did not show relative values, Azevedo et al. (2011) and Laclau and Laclau (2009) also reported greater root density at $0-0.4 \mathrm{~m}$ depth. Typical values for sugarcane root mass up to 0.2 and $0.6 \mathrm{~m}$-depth are reportedly 50 and $85 \%$, respectively (Smith et al. 2005). 
(a)

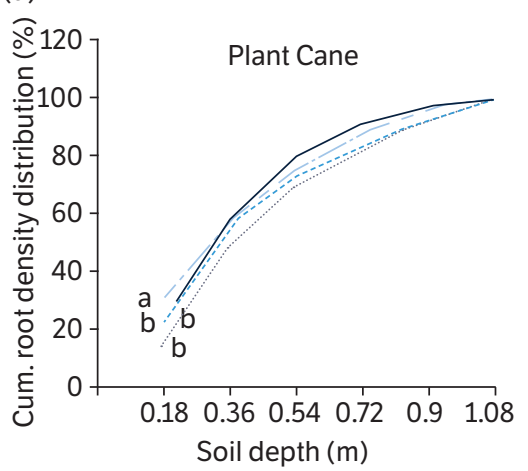

(b)

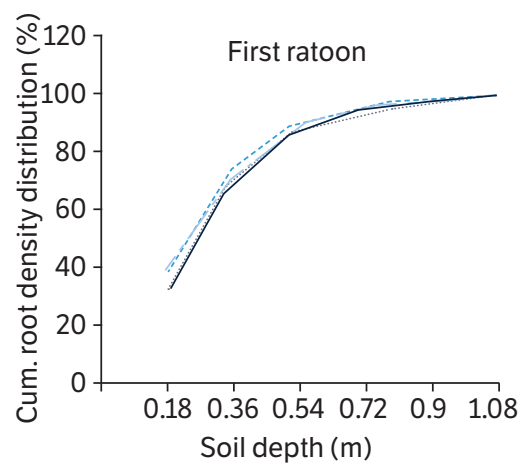

(c)

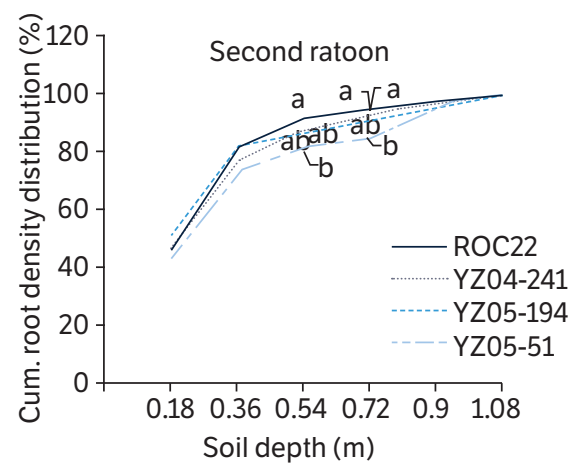

Figure 7. Root distribution and effective rooting depth of sugarcane genotypes ROC22, YZO4-241, YZ05-194, and YZ05-51as affected by crop cycle (plant cane (a)), first ratoon (b), and second ratoon (c)) and soil depth.

Note: For each crop and depth, genotypes with the same letter do not differ at $p \leq 0.05$ according to SPSS, but space limited the number of letters that could be shown. There were no significant differences at depths $>0.18 \mathrm{~m}$, no significant differences at any depth in b, and significant differences only at 0.54 and $0.72 \mathrm{~m}$ in c.

\section{Yield traits}

There were generally large genotypic differences in stalk height, stalk diameter, stalk number, and sugarcane yield in PC, FR, and SR crops (Table 1).

In PC and FR, YZ05-51 had greater absolute mean height than other genotypes. Stalk number and yield of ROC 22 were significantly higher than other genotypes in PC. In SR, YZ05-51 was significantly taller than the other genotypes. Stalk number and yield of ROC22, YZ05-51, and YZ04-241 were significantly greater than those of YZ05-194 in FR and SR. Stalk diameter did not differ among genotypes in PC and SR crops.

Table 1. Mean height, stalk diameter, stalk number, and sugarcane yield for genotypes in PC, FR and SR crop cycles.

\begin{tabular}{|c|c|c|c|c|c|}
\hline Crop & Genotypes & $\begin{array}{l}\text { Mean height } \\
(\mathrm{cm})\end{array}$ & $\begin{array}{l}\text { Stalk diameter } \\
(\mathrm{cm})\end{array}$ & $\begin{array}{l}\text { Stalk number } \\
\text { (stalks/ha) }\end{array}$ & $\begin{array}{l}\text { Yield } \\
\text { (t/ha) }\end{array}$ \\
\hline \multirow{4}{*}{ PC } & $\mathrm{ROC} 22$ & $75.89 c$ & $3.25 \mathrm{a}$ & $125561 \mathrm{a}$ & $43.96 \mathrm{a}$ \\
\hline & YZ05-51 & $98.33 a$ & $3.02 \mathrm{a}$ & $84448 b$ & $35.76 b$ \\
\hline & YZ04-241 & $86.56 b^{1}$ & $3.23 a$ & $66670 \mathrm{bc}$ & $27.27 \mathrm{c}$ \\
\hline & YZ05-194 & $87.11 b$ & $3.33 a$ & 44446 c & $23.73 c$ \\
\hline \multirow{4}{*}{ FR } & $\mathrm{ROC} 22$ & $381.4 \mathrm{~b}$ & $3.05 a$ & $68892 a$ & $144.6 \mathrm{a}$ \\
\hline & YZ05-51 & 424.9 a & $2.83 a$ & $63336 a$ & $132.1 a$ \\
\hline & YZ04-241 & $393.2 b$ & $3.04 \mathrm{a}$ & $56669 a$ & $112.2 \mathrm{a}$ \\
\hline & YZ05-194 & $378.1 \mathrm{~b}$ & $3.14 \mathrm{a}$ & $21112 b$ & $55.9 \mathrm{~b}$ \\
\hline \multirow{4}{*}{$\mathrm{SR}$} & $\mathrm{ROC} 22$ & $369.6 \mathrm{ab}$ & $2.98 a$ & $56669 a$ & $120.3 a$ \\
\hline & YZ05-51 & $427.5 \mathrm{a}$ & $2.69 \mathrm{~b}$ & $47780 a$ & $100.3 a$ \\
\hline & YZ04-241 & $378.8 a b$ & $3.14 a$ & $42668 a$ & $89.5 a$ \\
\hline & YZ05-194 & $325.8 \mathrm{~b}$ & $3.08 \mathrm{a}$ & $14445 b$ & $35.1 b$ \\
\hline
\end{tabular}

${ }^{1}$ Genotype means within a crop followed by a common letter do not differ at $p \leq 0.05$ according to SPSS.

\section{Yield and root correlations}

There tended to be a significant positive correlation between stalk number and total length in PC, FR, and SR (Table 2). Stalk height tended to be negatively correlated with root density and total length in PC. 
Table 2. Pearson correlations of root density with sugarcane traits and root length by soil depth in PC, FR, and SR crop cycles.

\begin{tabular}{|c|c|c|c|c|c|c|c|c|}
\hline \multirow{3}{*}{ Crop } & \multirow{3}{*}{ Plant trait } & \multicolumn{6}{|c|}{ Soil depth (m) } & \multirow{2}{*}{$\begin{array}{l}\text { Root length } \\
(\mathrm{cm})\end{array}$} \\
\hline & & $0.00-0.18$ & $0.18-0.36$ & $0.36-0.54$ & $0.54-0.72$ & $0.72-0.90$ & $0.90-1.08$ & \\
\hline & & \multicolumn{7}{|c|}{ Root density $\left(\mathrm{mm} \cdot \mathrm{cm}^{-2}\right)$} \\
\hline \multirow{3}{*}{ PC } & Stalk height & -0.19 & -0.35 & $-0.49^{\star}$ & -0.39 & -0.31 & 0.2 & -0.39 \\
\hline & Stalk number & 0.31 & $0.54^{* *}$ & $0.56^{* *}$ & $0.44^{*}$ & 0.33 & 0.01 & $0.44^{*}$ \\
\hline & Yield & 0.11 & 0.39 & 0.26 & 0.27 & 0.34 & 0.25 & 0.35 \\
\hline \multirow{3}{*}{ FR } & Height & 0.15 & 0.02 & 0.04 & 0.33 & -0.25 & -0.21 & 0.12 \\
\hline & Stalk number & 0.33 & $0.66^{\star *}$ & $0.68^{* *}$ & 0.37 & 0.16 & 0.16 & $0.68^{\star \star}$ \\
\hline & Yield & 0.35 & $0.63^{* *}$ & $0.69^{* *}$ & 0.38 & 0.07 & 0.15 & $0.75^{\star \star}$ \\
\hline \multirow{3}{*}{ SR } & Height & $0.43^{*}$ & 0.05 & 0.04 & 0.09 & 0.03 & 0.05 & 0.04 \\
\hline & Stalk number & $0.44^{*}$ & 0.05 & 0.29 & 0.12 & 0.01 & 0.10 & $0.60^{\star \star}$ \\
\hline & Yield & 0.39 & 0.03 & 0.25 & 0.02 & -0.07 & 0.06 & $0.55^{\star \star}$ \\
\hline
\end{tabular}

* "** Indicate significant correlation at $p<0.05$ and 0.01 , respectively, according to SPSS.

Positive correlations among stalk number and yield with $\mathrm{L}, \mathrm{L}_{\mathrm{A}}(0.18-0.54 \mathrm{~m})$ were significant $(\mathrm{p}<0.01)$ with the highest correlation $(r=0.75)$ occurring with $\mathrm{L}$ in FR. But in SR, correlations of height, stalk number, and yield with $\mathrm{L}_{\text {and }} \mathrm{L}_{\mathrm{A}}$ at $0.18 \mathrm{~m}$ were significant $(\mathrm{p}<0.05)$.

\section{CONCLUSION}

The good ratooning ability (ROC22 and YZ05-51) had higher RGR, L, and $\mathrm{L}_{\mathrm{A}}$ than a genotype with poorer ratooning ability (YZ05-194). About $59.2 \%$ of roots were distributed from $0-0.36 \mathrm{~m}$-depth and more than $85.0 \%$ were distributed at $0-0.72 \mathrm{~m}$-depth in PC. In FR and SR, however, more than $81.8 \%$ of roots were found at $0-0.54 \mathrm{~m}$-depth regardless of genotype; more than $46.2 \%$ of roots were distributed in at $0-0.18 \mathrm{~m}$-depth in SR.

\section{ACKNOWLEDGEMENTS}

This research was funded by Yunnan joint foundation for Agricultural basic research (2018FG001-067), Earmarked Fund for China Agriculture Research System (CARS-170101), the Earmarked Fund for Yunnan Province Agriculture Research System, Yunnan provincial innovation team for creating germplasm and developing new sugarcane cultivars of Yunnan Academy of Agricultural Sciences (2019HC013), International scientific and technological cooperation (2019IB008), Oversea top talents projects "Developing new sugarcane cultivars for Yunnan and the border cane region", and the overseas top talents project "Sugarcane Genetic Improvement and Extension".

\section{AUTHOR'S CONTRIBUTION}

Data curation, Liping Zhao, Yang K and Peifang Zhao; Investigation, Liping Zhao, Qin W, Zhao Y, Zhu J, Zan F and Zhao J; Methodology, Liping Zhao and Liu J; Weather Data, Lu X; Funding Acquisition, Liping Zhao, Wu C and Chen X; Writing - Original Draft, Liping Zhao; Writing - Review and Editing, Burner DM; Supervision, Liu J. 


\section{REFERENCES}

[FAO] Food and Agriculture Organization. (2014). Rome: FAOSTAT. [Accessed Mar. 18, 2020]. Available at: http://faostat.fao.org/default.aspx

Azevedo, M. C. B., Chopart, J. L. and Medina, C. C. (2011). Sugarcane root length density and distribution from root intersection counting on a trench-profile. Scientia Agricola, 68, 94-101. https://doi.org/10.1590/S0103-90162011000100014

Ball-Coelho, B., Sampaio, E. V. S. B., Tiessen, H. and Stewart, J. W. B. (1992). Root dynamics in plant and ratoon crops of sugar cane. Plant and Soil, 142, 297-305. https://doi.org/10.1007/BF00010975

Box Junior, J. E. (1991). Use of the minirhizotron-miniature video camera technique for measuring root dynamics. In L. Brussaard and M. J. Kooistra (Eds.). International Workshop on Methods of Research on Soil Structure/Soil Biota Interrelationships, Held at the International Agricultural Centre. Wageningen: Geoderma, 56, 133-141. https://doi.org/10.1016/B978-0-444-81490-6.50015-7

Cunha, F. F., Ramos, M. M., Alencar, C. A. B., Martins, C. E., Cóser, A. C. and Oliveira, R. A. (2010). Sistema radicular de seis gramíneas irrigadas em diferentes adubações nitrogenadas e manejos. Acta Scientiarum Agronomy, 32, 351-357. http://dx.doi.org/10.4025/ actasciagron.v32i 2.1020

Gascho, G. J. and Shih, S. F. (1983). Crop-water relations. In I. D. Teare, and M. Peet (Eds.). Sugarcane (p. 445-479). New York: John Wiley and Sons.

Laclau, P. B. and Laclau, J.-P. (2009). Growth of the whole root system for a plant crop of sugarcane under rainfed and irrigated environments in Brazil. Field Crops Research, 114, 351-360. https://doi.org/10.1016/j.fcr.2009.09.004

Liu, J., Basnayake, J., Jackson, P. A., Chen, X., Zhao, J., Zhao, P., Yang, L., Bai, Y., Xia, H., Zan, F., Qin, W., Yang, K., Yao, L., Zhao, L., Zhu, J., Lakshmanan, P., Zhao, X. and Fan, Y. (2016). Growth and yield of sugarcane genotypes are strongly correlated across irrigated and rainfed environments. Field Crops Research, 196, 418-425. https://doi.org/10.1016/j.fcr.2016.07.022

Lu, R. K. (2000). Methods of soil agricultural chemical analysis. Beijing: China Agricultural Science and Technology Press.

Muñoz-Romero, V., Benítez-Vega, J., López-Bellido, L. and López Bellido, R. J. (2010). Monitoring wheat root development in a rainfed vertisol: Tillage effect. European Journal of Agronomy, 33, 182-187. https://doi.org/10.1016/j.eja.2010.05.004

Ohashi, A. Y. P., Pires, R. C. M., Ribeiro, R. V. and Silva, A. L. B. O. (2015). Root growth and distribution in sugarcane cultivars fertigated by a subsurface drip system. Bragantia, 74, 131-138. https://doi.org/10.1590/1678-4499.0295

Otto, R., Trivelin, P. C. O., Franco, H. C. J., Faroni, C. E. and Vitti, A. C. (2009). Root system distribution of sugar cane as related to nitrogen fertilization, evaluated by two methods: monolith and probes. Revista Brasileira de Ciência do Solo, 33, 601-611. https://doi.org/10.1590/ S0100-06832009000300013

Smit, A. L., George, E. and Groenwold, J. (2000). Root Observations and Measurements at (Transparent) Interfaces with Soil. Root Methods. Berlin Heidelberg: Springer. https://doi.org/10.1007/978-3-662-04188-8_8

Smit, A. L. and Groenwold, J. (2005). Root characteristics of selected field crops: Data from the Wageningen Rhizolab (1990-2002). Plant and Soil, 272, 365-384. https://doi.org/10.1007/978-3-662-04188-8_8

Smith, D. M., Inman-Bamber, N. G. and Thorburn, P. J. (2005). Growth and function of the sugarcane root system. Field Crops Research, 92, 169-183. https://doi.org/10.1016/j.fcr.2005.01.017

Steindl, D. R. L. (1961). Ratoon stunting disease. In J. P. Martin, E. V. Abbott, and C. G. Hughes, (Eds.). Sugarcane Diseases of the World (p. 433-459). Amsterdam: Elsevier.

Vasconcelos, A. C. M., Casagrande, A. A., Perecin, D., Jorge, L. A. C. and Landell, M. G. A. (2003). Avaliação do sistema radicular da canade-açúcar por diferentes métodos. Revista Brasileira de Ciência do Solo, 27, 849-858. https://doi.org/10.1590/S0100-06832003000500009 
Wu, W. and Cheng, S. (2014). Root genetic research, an opportunity and challenge to rice improvement. Field Crops Research, 165, 111124. https://doi.org/10.1016/j.fcr.2014.04.013

Yahdjian, L. and Sala, O. E. (2002). A rainout shelter design for intercepting different amounts of rainfall. Oecologia, 133, 95-101. https:// doi.org/10.1007/s00442-002-1024-3

Zhao, P., Liu, J., Yang, K., Xia, H., Wu, C., Chen, X., Zhao, J., Yang, H., Li, J., Zan, F., Wu, Z., Yao, L., Li, F. and Zhao, L. (2015). Registration of 'YZ05-51' sugarcane. Journal of Plant Registrations, 9, 2, 172-178. https://doi.org/10.3198/jpr2014.03.0017crc

Zhao, P., Xia, H., Yang, K., Zan, F., Zhao, L., Qin, W., Yao, L., Chen, X., Liu, J., Zhao, J. and Wu, C. (2016). Sugarcane yield components and sugar content in ROC22 progeny populations. International Sugar Journal, 118, 26-33.

Zhao, P., Guo, J. Gao, X., Liu, G., Li, Y., Burner, D. M. and Yang, L. (2019). Small-scale mechanical harvesting and tractor-caused soil compaction reduce early growth in sugarcane. Agronomy, 9, 830-847. https://doi.org/10.3390/agronomy9120830 